\title{
The benefits of association of early diagnosis with bioactive materials for management of dental caries
}

Os benefícios da associação do diagnóstico precoce com materiais bioativos para o tratamento da cárie dentária Los beneficios de la asociación del diagnóstico precoz con materiales bioactivos para el tratamiento de la caries dental Angélica Feltrin DOS SANTOS ${ }^{1}$

Tainara Tonon CASTELLUCCIO ${ }^{1}$

Gerson Aparecido FORATORI-JUNIOR ${ }^{2}$

Daniela RIOS ${ }^{2}$

Linda WANG ${ }^{1}$

Juliana Fraga Soares BOMBONATTI ${ }^{1}$

${ }^{1}$ Department of Operative Dentistry, Endodontics and Dental Materials, Bauru School of Dentistry, University of São Paulo (FOB-USP) 17012-901 Bauru - SP, Brazil

${ }^{2}$ Department of Pediatric Dentistry, Orthodontics and Public Health, Bauru School of Dentistry, University of São Paulo (FOB-USP) 17012-901 Bauru - SP, Brazil

\section{Abstract}

The concept of minimally invasive dentistry certainly promoted significant changes towards more conservative dental caries management, which allows for quality information regarding the diagnosis, prognosis, and clinical management of dental caries even regarding the maintenance of restorative procedures. This case report aimed to highlight the relevance and feasibility of a streamlined caries disease management based on caries-risk determination and minimal invasive concepts associated with bioactive materials. A 13-year-old female patient sought dental care. Clinically, active white spot lesion on the occlusal surface of right upper first premolar coming from the fissures was noteworthy under moist condition. Bitewing radiography confirmed an interproximal carious lesion involving dentin. The cavity preparation was performed as more conservative as possible, removing the carious tissue selectively and treated with bioactive materials. After 12-month follow-up, successful performance of the restoration was seen while the patient caries-risk condition seems to be under control. This clinical case demonstrates that a correct diagnosis associated with smart materials and appropriate restorative procedures can offer effective and conservative results. Evidence-based treatment benefits patient avoiding unnecessary dental compromising and the maintenance of oral health.

Descriptors: Biocompatible Materials; Dental Caries; Dentin; Diagnosis; Dental Cavity Preparation.

\section{Resumo}

O conceito de Odontologia de Mínima Intervenção promoveu mudanças significativas em direção ao tratamento mais conservador da cárie dentária, o que permite obter informações com maior qualidade sobre o diagnóstico, prognóstico e manejo clínico da cárie, até mesmo com relação a manutenção de procedimentos restauradores. Este relato de caso teve como objetivo destacar a relevância e a viabilidade de uma abordagem simplificada da doença cárie, com base na determinação do risco de cárie e nos conceitos de odontologia de mínima intervenção associados aos materiais bioativos. Paciente do sexo feminino, 13 anos, procurou atendimento odontológico. Clinicamente, foi observada, na presença de umidade, uma lesão ativa de mancha branca na superfície oclusal do primeiro pré-molar superior direito localizada na região de sulco. A radiografia interproximal confirmou uma lesão de cárie interproximal envolvendo dentina. A preparação da cavidade foi realizada de forma mais conservadora possível, removendo o tecido cariado seletivamente e foi tratada com materiais bioativos. Após 12 meses de acompanhamento, foi possível observar uma condição satisfatória do tratamento prévio e desempenho bem-sucedido enquanto a condição de risco de cárie da paciente que se mostrou sob controle. Este caso clínico demonstra que um diagnóstico correto associado a materiais bioativos e procedimentos restauradores apropriados pode oferecer resultados efetivos e conservadores. O tratamento baseado em evidências beneficia o paciente, evitando comprometimentos dentários desnecessários e a manutenção da saúde bucal.

Descritores: Materiais Biocompatíveis; Cárie Dentária; Dentina; Diagnóstico; Preparo da Cavidade Dentária.

\section{Resumen}

El concepto de Odontología de Mínima Intervención ha promovido cambios significativos hacia un tratamiento más conservador de caries dental, lo que permite obtener información con mayor calidad sobre el diagnóstico, el pronóstico y el manejo clínico de la caries, incluso en relación con el mantenimiento de los procedimientos restauradores. Este informe de caso tuvo como objetivo resaltar la relevancia y la viabilidad de un enfoque simplificado para la enfermedad de caries, basado en la determinación del riesgo de caries y los conceptos de intervención mínima asociados con materiales bioactivos. Una paciente de 13 años buscó atención dental. Clínicamente, se observó una lesión activa de la mancha blanca en presencia de humedad en la superficie oclusal del primer premolar superior derecho ubicado en la región del surco. La radiografía interproximal confirmó una lesión de caries interproximal que involucra dentina. La cavidad se preparó de la manera más conservadora posible, eliminando selectivamente el tejido descompuesto y se trató con materiales bioactivos. Después de 12 meses de seguimiento, fue posible observar una condición satisfactoria del tratamiento previo y un desempeño exitoso, mientras que la condición de riesgo de caries del paciente que se mostró controlada. Este caso clínico demuestra que un diagnóstico correcto asociado con materiales bioactivos y procedimientos restaurativos apropiados pueden ofrecer resultados efectivos y conservadores. El tratamiento basado en la evidencia beneficia al paciente por evitar comprometidos dentales innecesarios y mantener la salud bucal.

Descriptores: Materiales Biocompatibles; Caries Dental; Dentina; Diagnóstico; Preparación de la Cavidad Dental.

INTRODUCTION

The concept of minimally invasive

dentistry (MID) certainly promoted significant changes towards more conservative dental caries management ${ }^{1-6}$. This knowledge fostered the development and application of new parameters and diagnostic tools, such as the Caries-risk assessments ${ }^{5}$ and International
Caries Detection and Assessment System $(\text { ICDAS })^{7}$, which allows for quality information regarding the diagnosis, prognosis, and clinical management of dental caries even regarding the maintenance of restorative procedure ${ }^{2,5}$. ICDAS is a system that guides professionals to focus on the detection of lesions, determine their severity 
and activity, and aid to categorize the caries risk assessment ${ }^{5}$. The MID also impacted carious lesion removal, allowing strategies that preserve maximum of demineralized dentin, which are able to recover by the natural dentin defense mechanisms $^{8}$. The scientific robust evidences have been encouraged professionals to deal in convenience purpose, eliminating the etiologic factors of caries while produce the minimal intervention as possible ${ }^{1,5}$.

Selective removal of caries is certainly the ultimate well-supported protocol that assure benefits for patient regarding the approach of caries lesions ${ }^{8-10}$. Conservative concepts stimulated the manufacturers to develop "smart" materials that have ensured relevant approaches for dental caries lesions ${ }^{11,12}$. Materials have been developed based on bioactive ingredients that provide chemical interaction with dental tissues despite favour for remineralization, with clinical evidences.

Therefore, it is expected that the clinical management of caries disease and consequent lesions would change all around the world. However, the main challenge to the adoption of MID is the resistance to change by the professionals. Educational of students during the undergraduate needs to be strongly addressed to practice of $\mathrm{MID}^{13}$. Due to recently more intense divulgation of scientific and technological developments, clinical signs, which were ignored in the past by professionals, have become easier to notice, allowing for the correct diagnosis, detection, and treatment of dental caries.

All this rationale improves these perspectives to get long-term use of the restorative procedures ${ }^{1,2,5}$. In this report, it was explored the importance of an accurate individual analysis to follow a more appropriate clinical approach. Based on the detected needs, bioactive materials were used to support these management. Therefore, the aim of this report is to highlight an integrative approach and systematic protocol from the diagnosis to the treatment of dental caries with smart materials, always considering the collaboration of the patient.

\section{CLINICAL CASE}

A 13-year-old female patient, accompanied by her guardian, sought dental care at the Bauru Dental School looking for orthodontic treatment. After check her medical history and perform detailed clinical oral examination, active white spot lesion (ICDAS 2) was observed on the occlusal surface of the right upper first premolar, coming from the fissures, under moist conditions and more evident after vigorous drying of the surface and under adequate illumination (Figure 1). In addition, a shadow could be seen in the distal area. The bitewing radiography confirmed an interproximal carious lesion involving dentin in tooth 14 (ICDAS 4). The radiography also showed initial caries lesion appearance on the mesial surface of right upper second premolar (Figure 2).

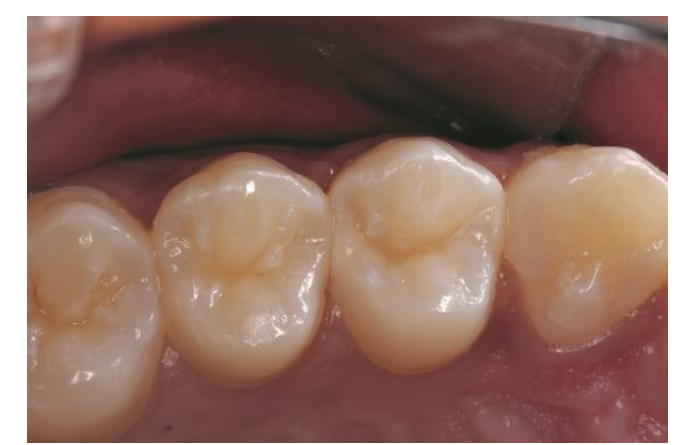

Figure 1: Occlusal view of initial aspect of teeth 14 and 15

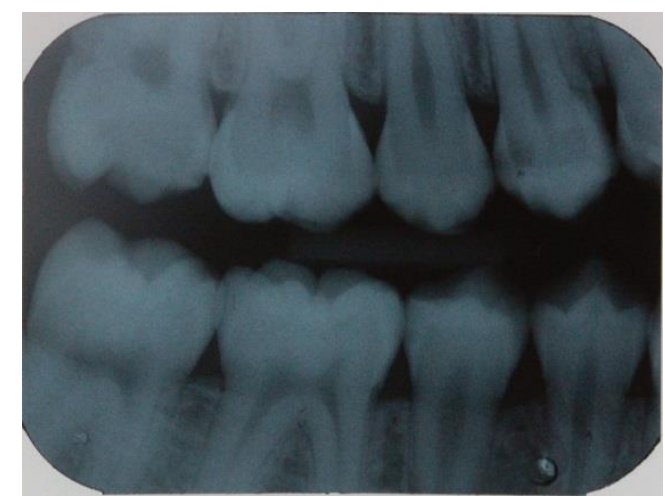

Figure 2: Bitewing radiograph. Notable radiolucent area close to enamel-dentin junction.

Based on the concepts of minimally invasive dentistry and ICDAS classification, the treatment plan was to selectively remove the carious tissue from the disto-occlusal lesion of tooth 14 and restore it with composite resin and to seal the remaining occlusal surface that was not involved in the cavity preparation.

In the first appointment, biofilm was highlighted using basic fuchsin (Eviplac tablets, Biodinâmica, Brazil) allowing patient to visualize her condition and to instruct her to perform proper oral hygiene. A cleaning was performed using paste (Herjos F, Coltene, Brazil) and Robinson brush. Caries management involved instruction on diet to control the disease. Oral hygiene and diet instructions were reinforced the following appointments. At the next appointment, a rubber dam was placed after administration of local anesthesia and cavity preparation was performed using a \#1012 diamond bur (KG Sorensen, Brazil) with high-speed rotation under constant cooling. The mesial surface of tooth 15 was protected with a universal matrix system (Tofflemire, TDV Dental, Brazil). Once access was achieved, a low-speed conventional bur, 
compatible with the size of the lesion, was used to selectively remove only the infected dentin, especially from the internal walls. During the removal of dentin caries, the tissue was removed up to reach a leather consistency, towards the axial wall. Therefore, it was possible to observe through direct vizualisation that the mesial face of tooth 15 was not cavitated (ICDAS 2), even though the radiograph indicated demineralization (Figure 3).

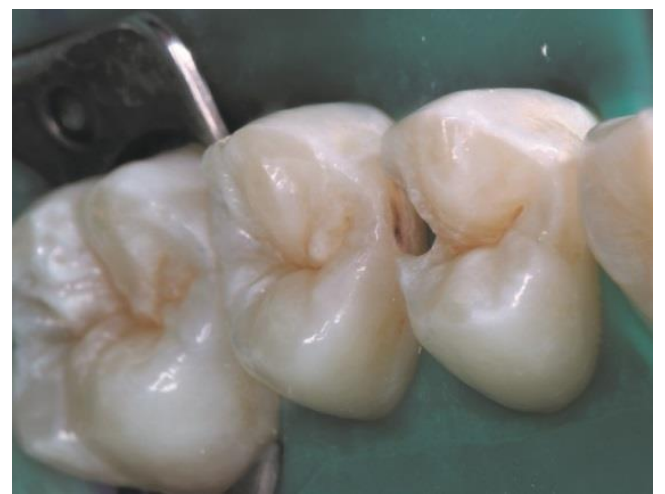

Figure 3: Access of the cavity preparation with a diamond bur on tooth 14 and mesial of tooth 15. Direct visualization of the mesial face of tooth 15: it is possible to observe the staining of the surface without cavitation.

After finishing the cavity preparation with gingival margin trimmer and cavity cleaning (Figure 4), the protection of pulpal wall was performed using a glass-ionomer liner, which was light activated for 40 seconds (Vitrebond, $3 \mathrm{M}$, USA). Then, $37 \%$ phosphoric acid gel was applied on the enamel margin for 15 seconds (Condac 37, Dentscare, Brazil), the primer (FLBond II primer, Shofu Japan) was applied and dried for 10 seconds, and the bonding agent was applied and light-cured for 5 seconds (FLBond II bonding agent, Shofu, Japan).

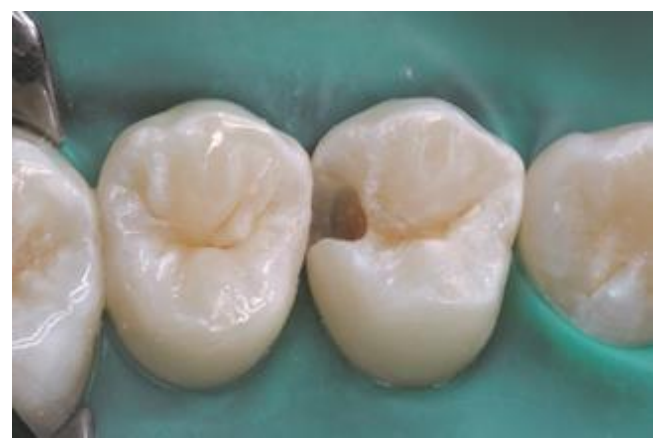

Figure 4: Final aspect of removal of carious tissue without remove affected dentin. The white spot lesion (occlusal of 14) was not involved in the preparation.

A matrix and wedge system (TDV Dental, Brazil) was placed on tooth 14 for restoration with composite resin consisting of an A1 flowable resin layer (Beautifil flow plus F00, Shofu, Japan). This resin is indicated by the manufacturer to be used as a reconstructionbase material due to its lower viscosity up to the level of the proximal contact point (Figure 5). Layers of A2 conventional composite resin
(Beautifil II, Shofu, Japan) were applied and light-cured up to the occlusal surface, allowing for carving of the restoration. Finally, occlusal adjustment was performed. In a third visit, the disto-occlusal restoration of tooth 14 (Figure 6) was finished and polished and the remaining pit and fissures not involved in the cavity preparation described above were sealed.

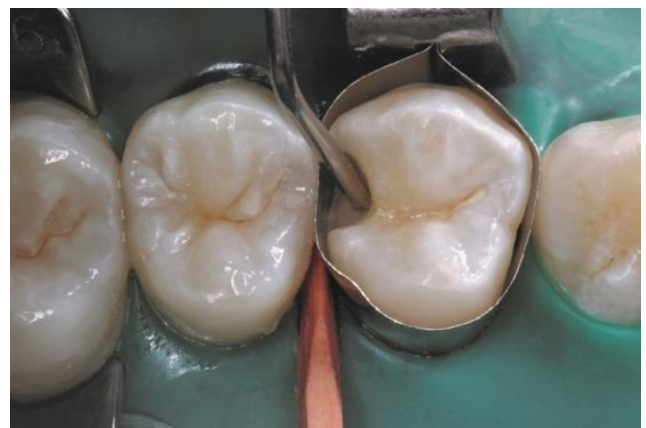

Figure 5: Insertion of A1 flowable resin (Beautifil flow plus F00).

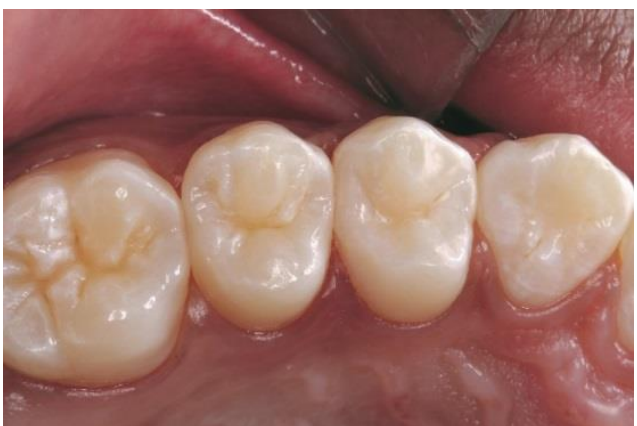

Figure 6: Final aspect of restoration based on the occlusal adjustment and finishing and polishing.

For this, cleaning with pumice and water, demarcation of the contact points, and absolute isolation were performed. The material of choice was the Beautisealant fluoride releasing pit \& fissure sealant system (Shofu, Japan). The primer was applied for 5 seconds and dried for 5 seconds followed by application of the sealant to occlusal surface, removal of the excess (Figure 7), and light-curing for 10 seconds. Finally, occlusal adjustment was performed, as well as finishing and polishing.

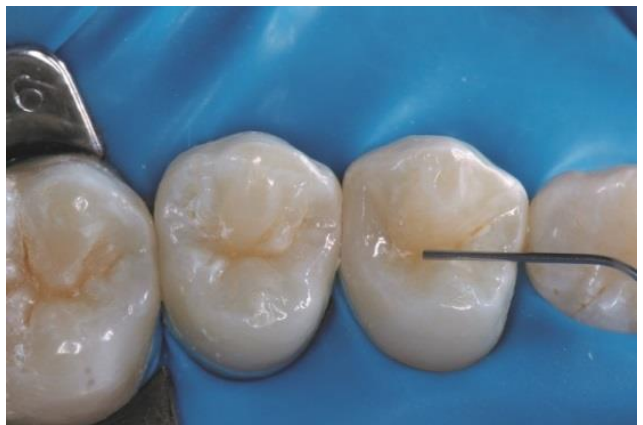

Figure 7: Sealant application (Beautisealant fluoride releasing pit \& fissure sealant system).

The immediate result can be seen in Figure 8 , resulting from an accurate diagnosis combined with a restorative procedure using materials that can chemically interact with the tooth structure. Twelve-month follow up showed 
the success of the approach, which presented satisfactory performance as shown in Figures 9 and 10.

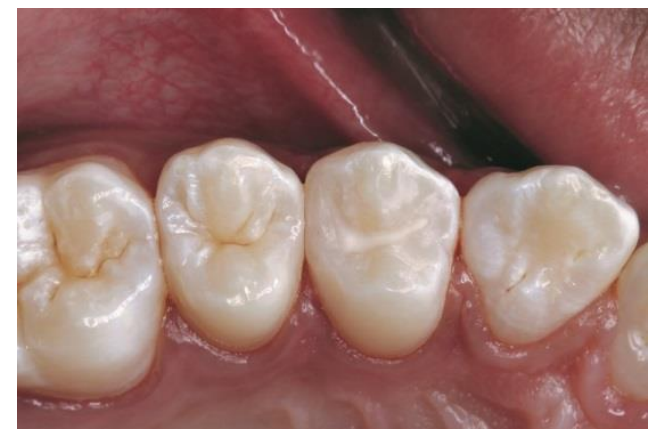

Figure 8: The immediate result after occlusal adjustment.

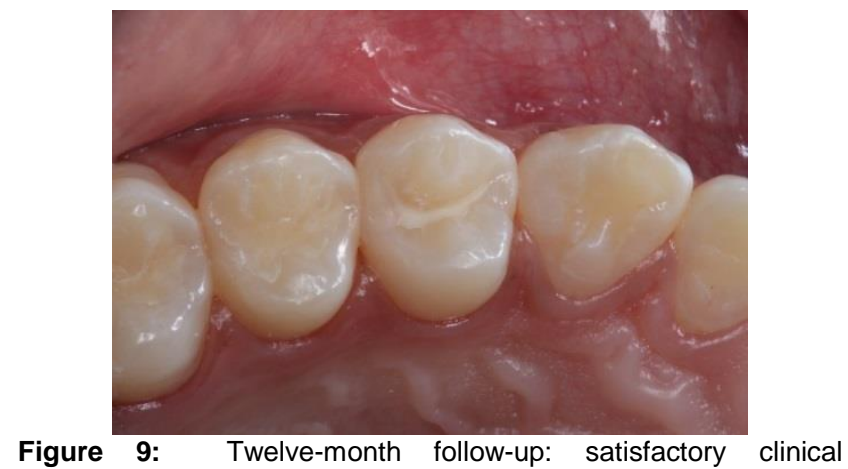
performance.

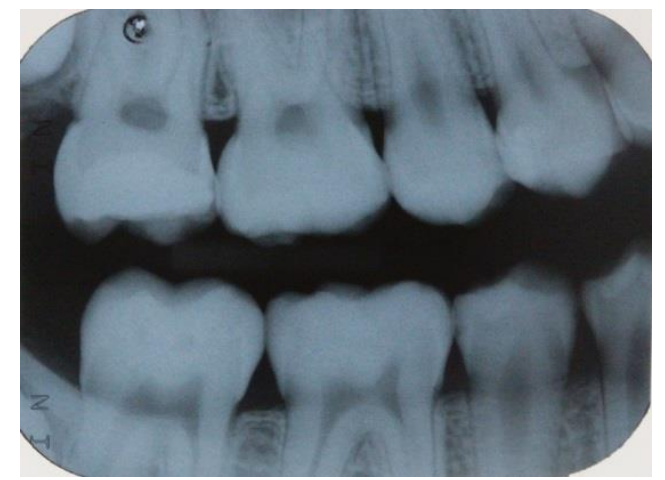

Figure 10: Bitewing radiograph after twelve months after treatment.

DISCUSSION

An integrative evaluation about patient holistic profile to conduct for the treatment of carious lesions is mandatory ${ }^{1,2,5}$. This case report highlights the importance of inter- and multidisciplinary approaches in order to reach an adequate and precise diagnosis and management of caries. This demeanor is of primary relevance and thus, in this report we point out that the treatment success depends firstly of using adequate diagnostic parameters, such as ICDAS. Based on these assessments, the decision about proper materials for dental treatment is taking into account. Based these principles, the concept of minimally invasive dentistry is strongly considered.

Schwendicke et al. ${ }^{7}$ indicated in 2016 that dental caries can be managed behaviorally by controlling its causative factors, mainly the supply of fermentable carbohydrates and the presence and maturation of dental biofilms ${ }^{11}$. Those authors also reported that effective management of the caries disease is characterized by detection of early lesions and subsequent accurate diagnosis, based on caries activity and risk assessment, and by preventing the occurrence of new carious lesions ${ }^{11}$. Once these factors are under control, the lesions are the second aspect to be solved.

In this case report, the active initial carious lesion, noted due to the presence of a shadow underneath enamel and detected during a detailed clinical exam, pointed to the possibility of compromised dentin, as an important sign for "hidden caries".

Early and accurate diagnosis enables better treatment possibilities, and helps to avoid the restorative cycle, in which eventual restoration repairs or replacements may lead to long-term tissue removal. When determining an early diagnosis, standardized references must be used in order to ensure adequate analysis of the patients' oral conditions ${ }^{5}$. The International Caries Detection and Assessment System (ICDAS II) was developed for use in clinical research, clinical practice, and for epidemiological purposes. ICDAS classifies clinical visual signs of carious lesions, predicting the progress rate of caries lesions ${ }^{14}$ from a code of 0 to $6^{11,14,15}$. The active white spots in the current case report (ICDAS 2) were noted due to the perceptible shadow of dentin and indicated dentin compromised by caries, which can be confirmed or not by radiographic exam. This finding indicates that these characteristic signs for a non-cavitated lesion. In this case report, the patient presented a moderately deep cavitated dentinal lesion in a permanent tooth. Schwendicke and co-authors in 2016 proposed the following treatments for shallow and moderate deep cavities: Selective removal of decay up to firm dentin; Atraumatic Restorative Treatment; Non-restorative Cavity Control; Fissure sealant (if non-cavitated) ${ }^{11}$.

The selective removal to firm dentin requires a resistance to a hand excavator on the cavity margins (peripheral dentin), leaving hard tissue on adjacent internal walls after removal. On the other hand, "leathery" tissue must be preserved on the pulpal walls of the preparation. In the current case report, it was intended to remove the soft dentin selectively on the floor of the preparation, as was indicated by the lesion radiographically extending less than a third of the pulpal floor or quarter of dentin.

Minimal intervention is desired not only to preserve dental tissues, but also to reach higher success rates of restorative procedures; as has 
been supported by two 5-year follow-up randomized clinical trials ${ }^{10}$.

This case report reveals that success can be reached by using new concepts and protocols, based on MID. Occlusal caries continues to be a clinical challenge for professional diagnosis but once detected, the current approaches include irreversible and conservative treatment of caries ${ }^{14}$.

It is recognized that the final outline of the definitive restoration should follow only the three-dimensional shape of the carious lesion and preserve all possible dental structure ${ }^{1}$. This is feasible because of the current knowledge of the biological factors that support caries disease associated with an early diagnosis, prevention, and advance of materials and restorative techniques. The current emphasis relies on stopping the disease progress, preventing demineralization, and promoting self-healing mechanisms. The practice of MID minimizes the unnecessary removal of dental tissue and allows the use of adhesive and biomimetic restorative materials ${ }^{1}$.

The Giomer technology mentioned above used to manufacture adhesive systems, composite resins, and sealants is based on the benefit of bioactive materials that have an antibacterial effect that were chosen for the present case. According to the manufacturer, these materials have Surface Pre-Reacted Glass (S-PRG) filler particles. The S-PRG filler releases 6 ions: fluoride, sodium, strontium, aluminium, silicate and borate. The ability to form an acid-resistant layer at the interface between material and dental structure is attributed to the release of fluoride and strontium by the material. These materials could reinforce the dental structure by reacting with hydroxyapatite, resulting in fluoride-apatite and strontium-apatite complexes ${ }^{15}$. Based on this, materials that release multiple ions may have a greater potential for long-term durability and selfrepair capability against demineralization at the bonding interface. Thus, all mechanisms of chemical interaction between restorative materials and dental structure contribute to the practice of modern and less invasive restorative dentistry. Other investigations on the ability to bond and seal altered, but not infected, dental tissue have been performed ${ }^{10}$.

Evidences strongly support professionals to practice a conservative dentistry and allows for their long-term performance. For sure, the awareness and involvement of the patients and/or their guardians is relevant to a whole patient-centered treatment.
CONCLUSION

In conclusion, when considering that many professionals still practice an obsolete concept of Cariology, inter- and multidisciplinary approaches to caries management are desirable to reach accurate diagnosis based on patient integrative assessment and early signs of carious lesions. Also, the use of adhesive materials that chemically interact with dental structure, are important to ensure the success and longevity of restorative treatment.

\section{REFERENCES}

1. Doméjean S, Banerjee A, Featherstone JDB. Caries risk/susceptibility assessment: Its value in minimum intervention oral healthcare. $\mathrm{Br}$ Dent J. 2017;223:191-97.

2. Askar H, Krois J, Göstemeyer G, Bottenberg P, Zero D, Banerjee A, et al. Secondary caries: what is it, and how it can be controlled, detected, and managed? Clin Oral Investig. 2020;24:1869-76

3. Ismail AI, Pitts NB, Tellez M, Benerjee A, Deery C, Douglas G, et al. The International Caries Classification and Management System $\left(\right.$ ICCMS $\left.^{\mathrm{TM}}\right)$ an example of a caries management pathway. BMC Oral Health. 2015;15:S9.

4. Guedes RS, Piovesan C, Ardenghi TM, Emmanuelli B, Braga MM, Ekstrand KR, et al. Validation of visual caries activity assessment: a 2-yr cohort study. J Dent Res. 2014;93: 101S-7S.

5. Hoefler V, Nagaoka H, Miller CS. Long-term survival and vitality outcomes of permanent teeth following deep caries treatment with stepwise and partial-caries-removal: a systematic review. J Dent. 2016;54:25-32.

6. Maltz M, Koppe B, Jardim JJ, Alves LS, de Paula LM, Yamaguti PM, et al. Partial caries removal in deep caries lesions: a 5-year multicenter randomized controlled trial. Clin Oral Investig. 2018;22:1337-43.

7. Schwendicke F, Frencken JE, Bjørndal L, Maltz M, Manton DJ, Ricketts D, et al. Managing carious lesions: consensus recommendations on carious tissue removal. Adv Dent Res. 2016;28:58-67.

8. Villat C, Attal JP, Brulat N, Decup F, Doméjean $S$, Dursun E, et al. One-step partial or complete caries removal and bonding with antibacterial or traditional self-etch adhesives: study protocol for a randomized controlled trial. Trials. 2016;17:404.

9. Vallittu PK, Boccaccini AR, Hupa L, Watts DC. Bioactive dental materials-Do they exist and what does bioactivity mean? Dent Mater. 2018;34:693-94.

10. Jandt KD, Sigusch BW. Future perspectives of resin-based dental materials. Dent Mater 2009;25:1001-6. 
11. Braga MM, Lenzi TL, Ferreira FR, Mendes FM, Raggio DP, Imparato JC et al. Impact of a tutored theoretical-practical training to develop undergraduate students' skills for the detection of caries lesions: study protocol for a multicenter controlled randomized study. JMIR Res Protoc. 2017;6:e155.

12. Dikmen B. ICDAS II criteria (International Caries Detection and Assessment System). J Istanb Univ Fac Dent. 2015;49:63-72.

13. Bjørndal L, Fransson $H$, Bruun G, Markvart M, Kjældgaard $M$, Näsman $P$, et al. Randomized clinical trials on deep carious lesions: 5-Year Follow-up. J Dent Res. 2017;96:747-53.

14. Carvalho JC, Dige I, Machiulskiene V, Qvist V, Bakhshandeh A, Fatturi-Parolo C, et al. Occlusal caries: biological approach for its diagnosis and management. Caries Res. 2016;50:527-42.

15. Kaga M, Kakuda S, Ida $\mathrm{Y}$, Toshima $\mathrm{H}$, Hashimoto $M$, Endo $K$, et al. Inhibition of enamel demineralization by buffering effect of S-PRG filler-containing dental sealant. Eur $\mathrm{J}$ Oral Sci. 2013;122:78-83.

\section{CONFLICTS OF INTERESTS}

The authors declare no conflicts of interests.

CORRESPONDING AUTHOR

Prof. Drª. Juliana Fraga Soares Bombonatti

Alameda Octávio Pinheiro Brisolla, 9-75,

Vila Universitária

17012-901 Bauru - SP, Brazil

Phone/Facsimile: +55-14-3235-8323

E-mail: wang.linda@usp.br

Received 04/07/2020

Accepted 23/10/2020 